\title{
Influence of sodium chloride and modified atmosphere packaging on microbiological, chemical and sensorial properties in ice storage of slices of hake (Merluccius merluccius)
}

\author{
Laura Pastoriza, Gabriel Sampedro, Juan J. Herrera \& Marta L. Cabo \\ Instituto de Investigaciones Marinas (C.S.I.C.), Eduardo Cabello, 6.- 36208, Vigo, \\ Spain
}

The effect of an optimum gas mixture $\left(50 \% \mathrm{CO}_{2}: 45 \% \mathrm{~N}_{2}: 5 \% \mathrm{O}_{2}\right)$ on hake slices (Merluccius merluccius) was studied when combined with a sodium chloride dip (5 min in $5 \% \mathrm{NaCl}$ solution). Exudation, water binding capacity (WBC), microbial growth, as well as undesirable chemical ( $\mathrm{pH}$, total volatile bases, lipid oxidation), and sensory alterations (raw fish odour) cooked fish flavour), were monitored. Values were compared with those obtained for air-stored samples and for MAP-stored samples in the absence of $\mathrm{NaCl}$. Sodium chloride dips showed a further inhibition of biochemical, microbiological and sensory deterioration of MAP-stored hake slices, so that total volatile bases and total viable counts values were significantly lower $(\mathrm{p}<0.05)$ than in fish stored under MAP conditions throughout all storage periods, and sensory properties were scored significantly higher. Exudation was also reduced in MAP-stored fish when previously dipped in sodium chloride solutions. Consequently, the shelf-life of hake slices was extended for 2 days when stored under MAP conditions, and for 8 days if dipped in sodium chloride solutions prior to MAP storage.

\section{INTRODUCTION}

Fish muscle is very susceptible to spoilage during ice storage so that a number of means have been investigated for preserving its quality and extending its shelf-life. Modified atmosphere packaging (MAP) increases the shelf-life of fish products (Dhananjaya and Stroud, 1994; Reddy et al., 1995; Pastoriza et al., 1996a,b) as high $\mathrm{CO}_{2}$ levels extend the lag phase of Gram negative aerobic bacteria that are mainly responsible for spoilage of fish muscle (Farber, 1991). 
Phosphates can inhibit the growth of Gram negative bacteria in fish stored in ice (Kim et al., 1995) and polyphosphates reduce drip loss in fish stored under MAP conditions (Alvarez et al., 1996). Sodium lactate delays deterioration of fish fillets (Williams et al., 1995) and suppresses the growth of Listeria monocytogenes (Shelef and Yang, 1991) and of Pseudomonas fragi (Harmayani et al., 1991). Potassium sorbate inhibits the growth of a number of pathogens in MAP-stored fish muscle (Elliot and Gray, 1981). Dipping fish in sodium chloride solutions preserves texture and colour when combined with MAP storage (Mitsuda et al., 1980) but its effect on bacterial growth and exudation has not been studied.

Consequently, the aim of the present work has been to study the combined effect of sodium chloride and MAP on microbial growth and chemical and sensory characteristics of ice-stored hake muscle. Subsequently, the shelf-life of hake slices was evaluated.

\section{MATERIALS AND METHODS}

Hake (Merluccius merluccius) was caught off the Galician coast (Northwest Spain) in March 1995 and stored in ice for about 5 h prior to processing in slices. Fish (20 kg) were gutted and washed with water. Slices ( $2 \mathrm{~cm}$ wide) were laid on polystyrene trays (5 slices per tray) and packed in retractile and coextrusionated multilayer film bags, sealed with a Tecnotrip vacuum-packaging machine. Fish was stored at $2 \pm 1^{\circ} \mathrm{C}$ during three weeks under the gas mixture $\left(50 \% \mathrm{CO}_{2}: 45 \% \mathrm{~N}_{2}: 5 \% \mathrm{O}_{2}\right)$ when combined with a sodium chloride dip (5 min in $5 \% \mathrm{NaCl}$ ). The ratio fish: gas was 1:2 (v/v). A control batch stored under air was also evaluated for comparative purposes. Samples were removed periodically for chemical, microbiological and sensory analyses. All measurements were performed in triplicate, unless otherwise stated.

Measurements of pH were carried out in a sample homogenized with water (ratio 1:2). Total volatile bases (TVB) were determined according to Lücke and Geidel (1935), as modified by Antonacopoulos (1960). TVB content was expressed as mg TVB-N $100 \mathrm{~g}^{-1}$ fish. Total bacterial count (TVC) was determined according to Pastoriza and Sampedro (1994). TVC was expressed as log TVC g-1 fish. Water-binding capacity (WBC) was measured according Pastoriza and Sampedro (1994). 
Hake muscle samples (4 g) were centrifuged in conical supports without membrane cones at $710 \mathrm{~g}$ for $30 \mathrm{~min}$ at $4^{\circ} \mathrm{C}$. Water binding capacity was expressed as 'water loss' which was the percentage loss in weight of the sample related to its initial moisture content. Exudation losses were evaluated from the loss of weight of the slices, and expressed as percentage of exudate related to initial fish weight. Tarladgis et al.'s method (1960) was used to determine malonaldehyde content, and the TBA number was expressed as mg malonaldehyde $\mathrm{kg}^{-1}$ sample.

The organoleptic assessment (flavour of the cooked product) was made on slices wrapped in polythene bags cooked in a microwave until the core temperature of each slice reached $70^{\circ} \mathrm{C}$. The samples were drained and allowed to cool to $20^{\circ} \mathrm{C}$. The cooking flavour was evaluated using the following scale: 1 , dislike extremely; 2 , dislike very much; 3, dislike moderately; 4, dislike slightly; 5, neither like nor dislike; 6 , like slightly; 7, like moderately; 8, like very much; 9, like extremely. The sensory evaluation was evaluated by a five member panel. The odour of raw muscle at the moment of opening the pack, was based on the following criteria: 10 , sea-fresh; 8 , neutral; 6 , slightly fishy; 4, fishy; 2, strongly fishy; 0, off-odours.

Differences between means were analysed by one-way analysis of variance (ANOVA) followed by Fischer's test.

\section{RESULTS AND DISCUSSION}

A significant increase $(\mathrm{p}<0.05)$ of $\mathrm{pH}$ was observed in overnight-stored control samples, and so on during the subsequent storage period, up to a value of 7.74 after two weeks ice storage (Fig. 1(a)). Fish stored under MAP conditions showed $\mathrm{pH}$ values significantly lower $(\mathrm{p}<0.05)$ than the control after 10 days storage, and after only 6 days when previously dipped in $\mathrm{NaCl}$ solutions. Sodium chloride dips reduced the $\mathrm{pH}$ significantly $(\mathrm{p}<0.05)$ in MAP-stored fish during the first 2 weeks storage. Carbon dioxide is absorbed into fish muscle surface, acidifying it via the formation of carbonic acid (Banks et al., 1980). The present study shows that the treatment of fish muscle with $\mathrm{NaCl}$ prior to ice storage acts synergistically with MAP on $\mathrm{pH}$ and TVB values of fish muscle during ice storage. This is thought to be a result of the effect of both factors on microbial growth. 
Likewise the $\mathrm{pH}$, TVB of air-stored fish increased significantly $(\mathrm{p}<0.05)$ throughout all

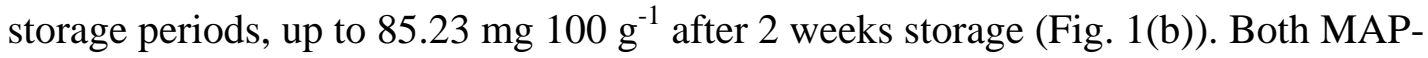
stored fish batches showed TVB values significantly lower $(\mathrm{p}<0.05)$ than the control after 5 days ice storage. TVB values of control samples were two-fold higher than those of MAP-stored fish and three- fold higher than NaCl-dipped fish stored under MAP after 14 days ice storage. Consequently, sodium chloride dips themselves also reduced TVB values significantly $(\mathrm{p}<0.05)$ during all storage period.

Assuming 35 mg TVB-N $100 \mathrm{~g}^{-1}$ as a limit of acceptability for consumption of fish, hake slices would have a shelf-life of 10 days, which would be extended to 12 days when stored under MAP conditions, and to 15 days if dipped in $\mathrm{NaCl}$ prior to being stored under MAP conditions.

Air-stored fish showed TVC values significantly $(\mathrm{p}<0.05)$ higher than MAP-stored fish after 2 days ice storage (Fig. 1(c)). Total viable counts of air-stored fish increased significantly $(\mathrm{p}<0.05)$ from 5 days ice storage up to two weeks storage. Bacterial counts of MAP- stored fish increased significantly $(\mathrm{p}<0.05)$ after 10 days ice storage, but this was avoided if fish were previously dipped in $\mathrm{NaCl}$ solutions. Thus, MAP-stored fish showed TVC values significantly higher $(\mathrm{p}<0.05)$ than MAP-stored fish dipped in $\mathrm{NaCl}$ solutions after 10 days ice storage. Consequently, $\mathrm{NaCl}$ further inhibited bacterial growth with no significant increases of TVC during the first 2 weeks ice storage. It is interesting to note that MAP prevented the TVC limit for acceptability being reached after two weeks storage, with values of $5.96 \log _{\text {TVC g}}{ }^{-1}$ for MAP-stored fish and of 4.99 for MAP-stored fish dipped in $\mathrm{NaCl}$. These differences decreased during the subsequent period of storage, reaching similar values.

Freshness of fish decreases as ice storage proceeds as a result of bacterial growth and its metabolic products. Consequently TVB has sometimes been used as an index of shown a high correlation between TVB and TVC in air- stored fish ( $\mathrm{r}: 0.86, \mathrm{p}<0.01)$, and also in MAP-stored fish, (r:0.84, $\mathrm{p}<0.01)$ and NaCl-dipped MAP-stored fish (r:0.99, $\mathrm{p}<0.01)$.

If $10^{6}$ bacteria per gram is taken as a limit of acceptability for consumption of fish, airstored hake slices would have a shelf-life of 7 days, whereas it would be extended up to 
14 days for MAP-stored fish and to 16 days for MAP-stored fish dipped in $\mathrm{NaCl}$. Consequently, it is noted that TVC should be taken as an index of acceptability, i.e. freshness, for ice-stored hake, but TVB could be used instead when hake slices are stored under MAP conditions.

Carbon dioxide extends the lag phase of Gram-negative aerobic bacteria (Reddy et al., 1992). These bacteria play a major role in fish spoilage by generating off-colours, offodours and a bad visual appearance of fish. Besides, $\mathrm{CO}_{2}$ can favour the growth of some Gram-positive bacteria, i.e. lactobacillus, that would compete with spoilage bacteria (Stenstrom, 1985).

Some salts alter the metabolism of bacteria, having a wide anti-microbial spectrum (Kim and Hearnsberger, 1994). This study has shown that dipping fish in sodium chloride solutions prior to MAP caused a further inhibition of bacterial growth. Consequently, TVB production and $\mathrm{pH}$ increases were reduced.

Exudation increased significantly $(\mathrm{p}<0.05)$ in air-stored fish after 10 days ice storage on (Fig. 2(a)). MAP-stored fish showed exudate values significantly $(\mathrm{p}<0.05)$ higher than the control after 7 days storage. Nonetheless, dipping in $\mathrm{NaCl}$ prior to MAP storage reduced exudation significantly $(\mathrm{p}<0.05)$. Thus, no significant differences were observed in exudation between control and $\mathrm{NaCl}$-dipped MAP-stored samples during the first ten days storage, but exudation was significantly lower $(\mathrm{p}<0.05)$ in the latter during the subsequent period of storage. Carbon dioxide favours exudation by acidifying fish muscle, so that the capacity of fish proteins to hold water is reduced (Cheftel and Cheftel, 1976). It has been previously found that, the higher the level of $\mathrm{CO}_{2}$, the lower the higher the exudation (Pastoriza et al., 1996a). The present study has shown that the negative effect of $\mathrm{CO}_{2}$ on exudation can be positively counteracted by dipping fish in $\mathrm{NaCl}$ solutions prior to MAP.

The water binding capacity of air-stored fish decreased significantly $(p<0.05)$ after 6 days storage on (Fig. 2(b)), showing a sharp decrease after 10 days storage. Thus, water binding capacity values showed a pattern similar to that followed by exudation. Significant decreases of WBC $(\mathrm{p}<0.05)$ were observed in MAP-stored fish throughout all storage period. However, if fish were dipped in $\mathrm{NaCl}$ prior to MAP storage, WBC 
showed slight increases during the first 10 days of storage, decreasing during the subsequent period of storage, as water was held by fish muscle. This shows that $\mathrm{NaCl}$ favours water binding of fish muscle, so WBC and exudate values do not further follow a similar trend, unlike the control. Consequently, MAP-stored fish dipped in $\mathrm{NaCl}$ were evaluated juicier than control samples, which were considered dry.

It has been reported that WBC variations are related to $\mathrm{pH}$ increases and muscle protein modifications (Stanley, 1983). The present study has also shown that large decreases of WBC and high exudate values are correlated with pH increases (over 7) in air-stored fish. This is suggested to be highly dependent upon bacterial growth and, consequently, spoilage of fish, which starts to become important after 10 days ice storage. A similar pattern was observed for MAP-stored fish, either dipped or not in $\mathrm{NaCl}$ solutions, although with some delay. However, MAP-stored fish showed higher initial exudate values as a result of the presence of $\mathrm{CO}_{2}$.

Significant differences $(\mathrm{p}<0.05)$ were observed in the TBA index between air-stored and both MAP-stored fish batches throughout all storage period (Fig. 2(c)). However, no significant differences were observed in the MAP-stored fish batches throughout the storage period, and no off-flavours were detected in any of the fish after 17 days ice storage.

The odour of fish (evaluated as odour when opening the package) changed as ice storage proceeded from neutral odour (day 0-1 for all samples) up to the appearance of off-odours once spoilage had taken place (Fig. 3(b)). Air-stored fish were sensorially rejected after 7 days storage. However, MAP-stored fish were accepted for a longer period, extending up to 14 days of storage and, if dipped in $\mathrm{NaCl}$ solutions prior to MAP storage, up to 17 days storage.

The flavour of cooked fish spoiled progressively during the period of storage (Fig. 3(a)). Air-stored fish was rejected after 7-8 days storage. Nonetheless, both MAP-stored fish batches did not show any significant change after one week of ice storage. Thus, MAPstored fish was judged as organoleptically acceptable during 14 days, whereas it was further extended to 16 days if previously dipped in $\mathrm{NaCl}$ solutions. 
A high correlation was observed between odour-scoring and bacterial growth, i.e. TVC, for all batches (r: 0.96, 0.95 and 0.95, for air-stored samples, MAP-stored samples and $\mathrm{NaCl}$-dipped MAP-stored samples, respectively, $\mathrm{p}<0.01)$. A high correlation was also observed between odour-scoring and TBV and TBA (r: 0.95, for both of them in airstored samples; r:0.85 and 0.95, respectively, in MAP-stored samples; and 0.95 for both of them in NaCl-dipped MAP-stored samples, $\mathrm{p}<0.01$ ).

Sodium chloride showed a further inhibition of biochemical, microbiological and sensory deterioration of hake slices stored under MAP conditions. It has been suggested that some bacteria cannot stand $\mathrm{NaCl}$ dips (5\%) as, consequently, they would be subjected to a too high osmotic pressure, so TVC decreases (Mitsuda et al., 1980). This surface effect is strengthened by the inhibitive effect that $\mathrm{CO}_{2}$ has on bacterial growth. It has been pointed out that $\mathrm{CO}_{2}$ inactivates some microbial enzymes, e.g. especially some hydrolases, and, thus, delays bacterial growth (Mitsuda et al., 1977). Carbon dioxide decreases $\mathrm{pH}$ in fresh fish, so that myosin and actin can form a strong network, preventing textural deterioration and the appearance of off-colours and off- odours in fish muscle (Connell, 1954).

The present study has shown that the combined use of MAP and $\mathrm{NaCl}$ dips has a synergistic effect during the storage of hake slices in ice, extending its shelf-life.

\section{CONCLUSIONS}

When sodium chloride was combined with MAP, a delay in chemical, microbiological and sensorial alterations was found. TVB and microbiological levels were significantly lower when MAP-stored samples had been previously dipped in $\mathrm{NaCl}$. Dipping in $\mathrm{NaCl}$ plus MAP reduced exudation markedly in comparison with MAP, i.e. 0.8 and 3.4\% for $\mathrm{MAP}+\mathrm{NaCl}$ dipping and MAP, respectively. This was also reflected by a significantly higher water binding capacity of NaCl-dipped MAP-stored samples. Sodium chloride dipping also significantly increased the time at which MAP-stored samples were rejected due to the development of off-odours. MAP-stored samples were refused after 14 days of storage whereas a neutral odour was scored in $\mathrm{NaCl}$ dipped samples after that storage. Control samples were rejected one week before MAP-stored samples. 


\section{ACKNOWLEDGEMENTS}

This work has been carried out with the financial support of the Science and Technology Interministry Comission (CICYT) within the Research Project coordinated with the Food Technology Section of AZTI Institute (Vizcaya) ALI93-0714-CO2-01 and of the Xunta of Galicia XUGA40204B96. We also wish to thank to Carlos Suarez for their collaboration in the sampling and in the application of analytical techniques.

\section{REFERENCES}

Alvarez, J. A., Pozo, R. and Pastoriza, L. (1996) Effect of a cryoprotectant agent (sodium tripolyphosphate) on hake slices preserved in modified atmosphere packaging. Food Science Technology International 2, 177-181.

Antonacopoulos, N. (1960) Verbesserte Apparatur zur quantitativen Destillation wasserdampfflüchtiger Stoffe. Zeitschnift Lebensmittel Untersuchung Forschung 113, 113-116.

Banks, H., Nickelson, R. and Finne, G. (1980) Shelf-life studies on carbon dioxide packaged finfish from the Gulf of Mexico. Journal of Food Science 45, 157-162.

Connell, J. J. (1954) Studies on the proteins of fish skeletal muscle. 3. Cod myosin and cod actin. Biochemistry Journal 58, 360-367.

Cheftel, J. F. and Cheftel, H. (1976) Introduction à la biochimie et à technologie des aliments, Vol. 1 et 2. Entreprise Moderne d'Edition, Paris.

Dhananjaya, S. and Stroud, G. D. (1994) Chemical and sensory changes in haddock and herring stored under modified atmosphere. International Journal of Food Science and Technology 29, 575-583.

Elliott, P. H., and Gray, R. J. H. (1981) Samonella sensitivity in a sorbate/modified atmosphere combination system. Journal of Food Protection 44, 903-908.

Farber, J. M. (1991) Microbiological aspects of modified-atmosphere packaging technology. A review. Journal of Food Protection 54, 58-70.

Harmayani, E., Sofos, J. and Schmidt, G. R. (1991) Effect of sodium lactate, calcium lactate and sodium alginate on bacterial growth and amino peptidase activity. Journal of Food Safety 11, 269-283. 
Kim, C. R. and Hearnsberger, J. O. (1994) Gram negative bacteria by lactic acid culture and food preservatives on catfish fillets during refrigerated storage. Journal of Food Science 59, 513-516.

Kim, C. R., Hearnsberger, J. O., Vickery, A. P., White, C. H. and Marshall, D. L. (1995) Extending shelf life of refrigerated catfish fillets using sodium acetate and monopotassium phosphate. Journal of Food Protection 58, 644-647.

Lücke, F. and Geidel, W. (1935) Bestimmung des flüchtigen basischen Stickstoffs in Fischen als Masstabb für ihren Frischezustand. Zeitschnift Untersuchung Lebensmittel 70, 441-417.

Mitsuda, H., Yamamoto, A., Suzuki, F., Nakajima, K., Yasumoto, K. and Kawai, F. (1977) Identification and properties of reactive sites in protein capable of binding carbon dioxide in a gas-solid phase system. Journal of Nutrition Science and Vitaminol 23, 145.

Mitsuda, H., Nakajima, K., Mizuno, H. and Kawai, F. (1980) Use of sodium chloride solution and carbon dioxide for extending shelf-life of fish fillets. Journal of Food Science 45, 661-666.

Pastoriza, L. and Sampedro, G. (1994) Influence of ice storage on ray (Raja clavata) wing muscle. Journal of the Science of Food Agriculture 62, 9-18.

Pastoriza, L., Sampedro, G., Herrera, J. R. and Cabo, M. L. (1996a) Effect of modified atmosphere packaging on shelf- life of iced fresh hake slices. Journal of the Science of Food Agriculture 71, 541-547.

Pastoriza, L., Sampedro, G., Herrera, J. R. and Cabo, M. L. (1996b) Effect of carbon dioxide atmosphere on microbial growth and quality of salmon slices. Journal of the Science of Food Agriculture 72, 348-352.

Reddy, N. R., Armstrong, D. J., Rhodehamel, E. J. and Kautter, D. A. (1992) Shelf-life extension and safety concerns about fresh fishery products packaged under modified atmospheres: a review. Journal of Food Safety 12, 87-118.

Reddy, N. R., Villanueva, M. and Kautter, D. A. (1995) Shelf life of modifiedatmosphere-packaged fresh Tilapia fillets stored under refrigeration and temperature-abuse conditions. Journal of Food Protection 58, 908-914.

Shelef, L. A. and Yang, Q. (1991) Growth suppression of Listeria monocytogenes by lactates in broth, chicken and beef. Journal of Food Protection 54, 283-287. 
Stanley, D. W. (1983) Relation of structure to physical properties of animal material. In Physical Properties of Foods, eds M. Peleg and E. B. Bagley, pp. 157-206. AVI Publishing Company Inc., Westport, CT, USA.

Stenstrom, I. M. (1985) Microbial flora of cod fillets (Gadus morhua) stored at $2^{\circ} \mathrm{C}$ in different mixtures of carbon dioxide and nitrogen/oxygen. Journal of Food Protection 48, 585-589.

Tarladgis, B. G., Watts, B. M., Younathan, M. T. and Dugan, L. (1960) A distillation method for the quantitative determination of malonaldehyde in rancid foods. Journal of American Oil Chemistry Society 37, 44-48.

Wang, M. Y. and Brown, W. O. (1983) Effect of elevated $\mathrm{CO}_{2}$ atmosphere on storage of freshwater crayfish (Pacifastacus leniusculus). Journal of Food Science 48, 158-159.

Williams, S. K., Rodrick, G. E. and West, R. L. (1995) Sodium lactate affects shelf life and consumer acceptance of fresh catfish (Ictalurus nebulosus, marmoratus) fillets under simulated retail conditions. Journal of Food Science 60, 636-639. 
Fig. 1. $\mathrm{pH}$ values, total volatile bases and total viable count from MAP and control hake slices during storage at 2.1_C. Treated samples: batch $1\left(\mathrm{CO}_{2}, 50 \% ; \mathrm{N}_{2}, 45 \% ; \mathrm{O}_{2}, 5 \%\right)$; batch $2\left(\mathrm{CO}_{2}, 50 \% ; \mathrm{N}_{2}, 45 \% ; \mathrm{O}_{2}, 5 \%\right.$ and $\left.\mathrm{NaCl}, 5 \%\right)$. Vertical bars represent SD.

Fig. 2. Weight loss water binding capacity values and thiobarbituric acid from MAP and control hake slices during storage at $2.1^{\circ} \mathrm{C}$. Treated samples: batch $1\left(\mathrm{CO}_{2}, 50 \%\right.$; $\mathrm{N}_{2}$, $\left.45 \% ; \mathrm{O}_{2}, 5 \%\right)$; batch $2\left(\mathrm{CO}_{2}, 50 \% ; \mathrm{N}_{2}, 45 \% ; \mathrm{O}_{2}, 5 \%\right.$ and $\left.\mathrm{NaCl}, 5 \%\right)$. Vertical bars represent SD.

Fig. 3. Flavour and initial odour values from MAP and control hake slices during storage at 2.1_C. Treated samples: batch $1\left(\mathrm{CO}_{2}, 50 \% ; \mathrm{N}_{2}, 45 \% ; \mathrm{O}_{2}, 5 \%\right)$; batch $2\left(\mathrm{CO}_{2}\right.$, $50 \% ; \mathrm{N}_{2}, 45 \% ; \mathrm{O}_{2}, 5 \%$ and $\mathrm{NaCl}, 5 \%$ ). The cooking flavour was evaluated using the following scale: 1 , dislike extremely; 2 , dislike very much; 3 , dislike moderately; 4 , dislike slightly; 5, neither like or dislike; 6 , like slightly; 7, like moderately; 8 , like very much; 9, like extremely. The odour of raw muscle at the moment of opening the pack, was based on the following criteria: 10 , sea-fresh; 8 , neutral; 6 , slightly fishy; 4 , fishy; 2, strongly fishy; 0 , off odours. Vertical bars represent SD, $\mathrm{n}=5$. 